\title{
THE ROLE OF LANDFORMS IN THE LOCATION OF ROMAN FORTIFICATIONS IN NORTHERN TRANSYLVANIA (TIHĂU-CĂȘEIU AREA) AND THE PRODUCTION OF PLACE AND REGIONAL IDENTITY
}

\author{
Alexandra-Maria COLCER \\ Babeş-Bolyai University, Cluj-Napoca, Faculty of Geography, Territorial Identities and Development Research \\ Centre, ROMANIA \\ colcer_alexandra@yahoo.com \\ Ioan-Aurel IRIMUȘ \\ Babeş-Bolyai University, Cluj-Napoca, Faculty of Geography, ROMANIA \\ aurel.irimus@ubbcluj.ro \\ DOI: http://doi.org/10.23740/TID120211
}

\section{ABSTRACT}

By combining the technical and empirical research methods, this article aims at establishing the role of the landforms in the location of Roman settlements and fortifications in Northern Transylvania, Romania, focusing on the Dacia Porolissensis (province of the Roman Empire) border and how (and if) these elements are still present in the local identity. Cartographic methods helped us to achieve the technical part. We used the ArcMap 10.6 software. The result obtained through digital modelling is the morphometric identification of the territorial discontinuities. Considering the qualitative aspects, the used methods were the traditional ones: analysis, synthesis, induction, and deduction. These methods enabled us to better understand how these settlements influenced the regional identity. The results of the study are emphasizing the strategical importance of the landforms in establishing the Roman castrum, and it demonstrates how (or if) the associated settlements remained present in the locals' mentality and influenced the regional identity.

Keywords: Roman fortification, Dacia Porolissensis, morphometric identification, regional identity

Cite this article as: Colcer, A.-M, Irimuș, I.A. (2020). The Role of Landforms in the Location of Roman Fortifications in Northern Transylvania (TihăuCășeiu Area) and theProduction of Place and Regional Identity. Territorial Identtiy and Development, 6(1), 5-21. DOI: http://doi.org/10.23740/TID120211

\section{INTRODUCTION}

Since the Neolithic, the individual's need for defence has gradually intensified. It was caused by the sedentary life, the cultivation of the land, the preparation of food and other supplies, plus a series of conflicts with other people for various resources. In those times, the inhabitants built their settlements in easily accessible locations, ditches, and palisades (Comşa, 1987, p. 133). Over time, several settlements evolved into strongholds, positioned on high but flat ground surfaces, where they benefited from natural protection and good visibility over their territorial interest. Thus, the defensive function is added to the surveillance function of the territory (only where land morphology and morphodynamics allowed it). 
One of the best examples of landform's potential use for defence and surveillance is the Roman Empire, with its limes, roads, settlements and fortifications. The word limes was used by Latin writers to denote a marked or fortified frontier. Over time, the historians adapted this word as an equivalent for the frontiers of the Roman Empire at its greatest extent in the $2^{\text {nd }}$ century A.D. It stretched over 5,000 five thousand km from "the Atlantic coast of Scotland, through more or less the middle of Europe to the Black Sea, and from there to the Red Sea and across North Africa back to the Atlantic coast" (Muzeul Județean Mureș, 2020).

The geostrategic thinking of the Romans is reflected on the way they established their borders, especially the limes and its components. None of the elements of fortification was established by chance. Everything was built in the right place, to maximize the political and economic advantages.

The Roman roads and fortification systems have several roles: recognition of boundaries and belonging to that territory; surveillance of the people and goods traffic/movements in the border area; immediate visual and sound communication in case of danger; a rapid and safe movement of troops; removal of groups that threatened the borders; army supply (Marcu, 2017). Their strategic thinking in establishing the limes infrastructure and the fortification systems was based on maximizing the potential of the landforms (altitude, slopes, drainage, natural resources).

As can be seen, the landform, its potentials and constraints, had and still has an essential role in strategic planning (delimitation of administrative territories, establishment of the roads and fortifications). All these elements contributed to keeping the territorial unity, provided the conditions for the transport of materials, goods and people, and the development of economic relations.

Landforms do not only support the daily activities but also provide visible and invisible traces of historical power structures, by adapting the landforms to different functions, representing the common practices which existed in the landscape and the immaterial laws and customs which lie over the land (Butler et al., 2019, p. 316). We are analysing the way all these aspects created (or not) a certain place identity.

\section{THEORETICAL BACKGROUND}

Most of the time, social psychologists, political scientists and human geographers studied the regional identity and interpreted this concept as being "the main 'glue' that holds society together, as the source of strong anchorage to a territory" (Capello, 2018, p. 142). This main "glue" is created through time. The power of territorial identities lies in the fusion of social action and symbols into nationalized practices and discourses that are significant in terms of national identity (Paasi, 2000, pp. 11-12).

Identity also provides a sense of belonging, "creating rhetoric through which practices and relations can be legitimized" (Dixon \& Durrheim, 2000, p. 33). These practices and activities contribute to the formation of regional identities (Colcer, 2017, p. 144). "The creation of identity is a constant process of identification, a process that develops through interactions with other individuals and our surroundings" (Butler et al., 2019, p. 316). Through this process, we are rewriting the self and the social collective day by day (Paasi, 2002, p. 144). 
Paasi underlines that "the identity of a region refers to those distinguishing physical, cultural, and historical features that make one region different from another" (Paasi, 2003, quoted in llovan, 2016b, p. 263). Regional consciousness refers to the way people "identify themselves with the region as the whole of institutionalized practices, discourses, and symbols" (Paasi, 2003, quoted in llovan, 2016b, p. 263). If there is not a regional identity, there is not a regional consciousness coming from the people either. It is a dependent mechanism. Identity does not exist without consciousness, and consciousness is given only by the identity aspects.

Identity is recognized as "being derived from experience, reflection on those experiences, and the actions undertaken as a consequence of them" (Gecas \& Burke, 1995, p. 57). Yet, while experiences have both social and geographical context, studies on identity have tended to favour history over geography, because the regional identity involves mainly an evolutionary process of cultural and social aspects than a pure spatial determinism: "The physicality of the environment in which identity is formed has traditionally been overlooked" (Dixon \& Durrheim, 2000, p. 40). Also, identity has place-related implications (Twigger-Ross \& Uzzell, 1996, p. 206).

All in all, the identity is given by the material (e.g. constructions, statues, specific clothes) and immaterial factors (practices, experiences, rituals, etc.); all these elements create the heritage. In order to preserve and capitalize on this heritage, the most important aspect is "the attitude of the affected population towards heritage protection" (Ilovan, 2016a, p. 274; cf. also llovan, 2008, 2009; llovan, Voicu \& Colcer, 2019; Maroși et al., 2019) and the youth's involvement, which "is crucial for transmitting cultural values to future generations" (llovan, 2016b, p. 241). Tolerance, cultural acceptance, and the promotion of cultural specificities are also needed (Scridon \& Colcer, 2017, p. 202; Scridon \& llovan, 2015, 2016).

\section{METHODOLOGY}

The employed research materials are the following: scientific works of history, geography (geomorphology, hydrology, general monographies), musicology, linguistics (etymology); visual materials (maps, photographs, sketches, satellite images), as well as experts' (historians, musicians, geographers) and locals' opinions and representations of place and regional identity (for researching representations, cf. llovan et al., 2019).

Procedures for data collecting were based on bibliographic methods, extracting information from scientific publications (in hard copies or online) and from various web sources (scientific articles, newspapers, websites). We also collected data through the semi-structured interviews with archaeologists, historians, and geographers (geomorphologists). The four expert interviews were conducted by phone. We collected visual data like photographs, maps, drawings (in hard copies and online). We gathered information about the landforms through direct observation during the field research, when we also had spontaneous discussions, and consultations with the locals.

Texts were researched thorough the following methods: textual analysis, content analysis, discourse analysis. Given the fact that most of the texts were written by historians, we used these methods in order to gather new concepts, and adapt them to our study. Illustrative materials were analysed through visual methods: visual and content analysis. This step allowed us a better understanding of the historical reality. The community diagnosis was applied to Romanian historians in order to analyse anthropological aspects (perspectives on the limes, the 
way of organizing life in the Romanian province, behaviours, values systems, and codes of conduct).

For finding the identity aspects (cf. also llovan, 2015), we used the internet-mediated research method. We did Google searches on the communes of the study area. We divided the resulted websites into three categories: (1) official websites, which contained the online platforms of the administrations (local, county); general useful information sites, like Wikipedia or tourism centres; (3) social media pages.

The cartographic part was created using ArcMap 10.6 with an online database provided by Copernicus - the European Union's Earth Observation Program, which is being coordinated and managed by the European Commission. Other shapefiles were downloaded from geo-spatial.org or retrieved from our personal archive. The limes marking was performed based on archaeological evidence that confirms its existence in the study area. There are several archaeological studies focused on the Transylvanian limes (Ferenczi, 1988, 1991, 1992).

\section{RESULTS AND DISCUSSION}

\section{Study area}

In Romania, the limes follows the interior of the Carpathian arch; the entrance to the country is through the south of Banat, a little further north of the Danube, facing north, through the east of the Apuseni Mountains. From the Tihău area, the limes continues to the east, to the foot of the Călimani, following the Orientals to the south, and crosses the Southern Carpathians on the Olt line. Maintaining the North-South direction, it leaves the country next to Corabia.

The delimitation of the study area was made following the path of the limes (see Figure 1). Historical sources and recent archaeological discoveries mention the existence of different parts of the fortification system. We thus joined those points, resulting the study area.

The defence system of the limes section in the study included (1) the auxiliary camps - Tihău to the west and Cășeiu (castrum Samum) to the east -, (2) a smaller fortification (burgus) in Podișu, (3) a border road and (4) a network of towers with observation and signalling function (see Figure 1). Between the two camps, at about $45 \mathrm{~km}$, the Cluj archaeologist Ferenczi $(1988,1991)$ identified 34 towers and a possible burgus (fair in Romanian), in Podișu (Ferenczi, 1988, p. 258; Marcu et al., 2017, p. 23) Ferenczi (1988) described an alignment of towers located south of the Someș River, between Tihău and Podişu settlements, on the Şimişna-Gîrbou Hills and two alignments of towers located north of the Somes River course, one on the Prisnel Peak, less safe, and another located in the Ciceului Hills. The historian from Cluj also mentions the existence of towers between Gostila and Răzoare localities, in the north of Ciceului Hills, which he considers more or less safe (Ferenczi, 1988, p. 257).

Starting from the Roman period, the study area has always been a border area. Moreover, it has been fragmented - parts of it were included in various administrative units (districts, shires, counties). After the withdrawal of the Roman legions and administration from Dacia (271-275 A.D.), the remained Dacian-Roman population faced the frequentmigratory waves of the Goths, the Huns, the Slavs, the Hungarians, etc. in the following centuries. The Hungarians settled in the Carpathian-Basin in the $9^{\text {th }}$ century and in the next centuries the study area was part of various forms of government and administrative units, like the Hungarian Kingdom (in the Middle Ages) or the Transylvanian principality. From the $19^{\text {th }}$ century, the study area was 
included in the Austro-Hungarian empire, and since 1918, the territory became part of the newly formed Kingdom of Romania.

It is challenging to be a border region or to have a border right next to your area because "borders are often pools of emotions, fears, and memories that can be mobilized apace for both progressive and regressive purposes" (Johnson et al., 2011, p. 62). Borders are created when changes in management structures occur. Those changes can be desired/expected or unwanted/unexpected. Changes are a sign of historical events of a different level of importance - local, regional, national, or global. That is why borders are rooted in historically contingent practices and discourses that are related to national ideologies and identities (Johnson et al., 2011, p. 63).

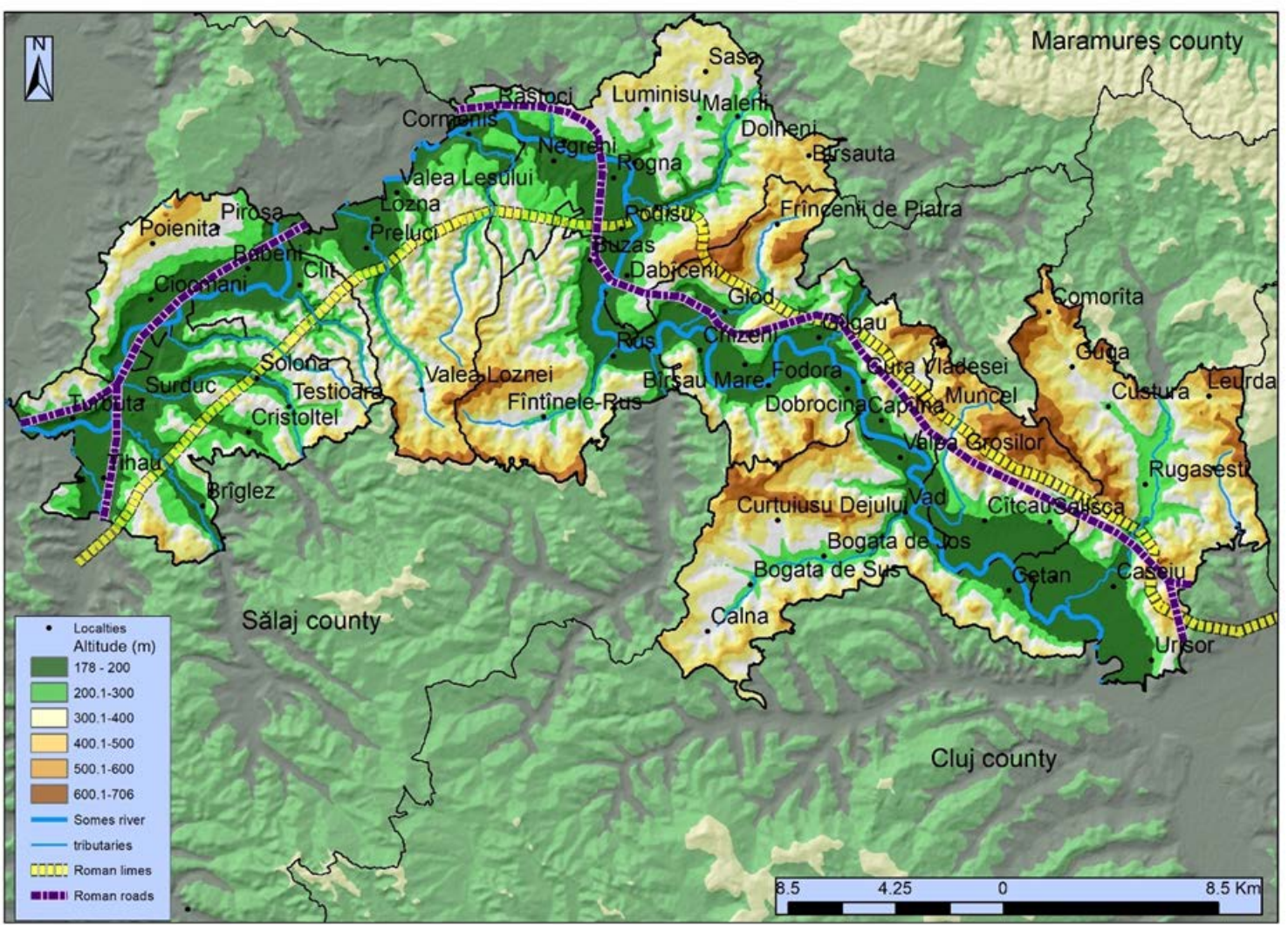

Figure 1: Location map

Author: A.-M. Colcer. Source of data: Shapefiles - GeoSpatial Website \& Copernicus Programme

As far as the spatial organization is concerned, the study area has been divided in various administrative units over time. For example, between the $13^{\text {th }}$ and $16^{\text {th }}$ centuries, the Eastem part was included into the Ciceului Region (Căşeiu de Jos, Căşeiu de Sus, Salişca, Câţcau, Gâlgău, Muncel, Căpâlna, lleanda, Glod (Potra, 2017, p. 93). Nevertheless, in present times, only 6,25\% of the Cășeiu and Câțcău inhabitants identify themselves as being part of the Ciceului Land (Potra, 2017, p. 116). In the $20^{\text {th }}$ century, there were more than ten changes in the administrative organization. The western part of the region was part of Sălaj County, while the most significant part of the region was included in the Someș County. Between 1952 and 1968, it was part of the Cluj Region. Since 1968, the territorial-administrative units of Cășeiu, Vad, Câțcău, and Ileanda 
were included into Cluj County, while Rus, Lozna, Băbeni, Rus, Surduc were included into Sălaj County (Săgeata, 2003, p. 16).

Taking into account the landforms, on the Western side of the territory (in the Tihău-lleanda subsector), we can distinguish the presence of the Meseșului Mountains peaks and the summits of Mare-Prisaca Hill, Preluca, mainly composed of crystalline rocks, connecting towards the east (in the lleanda-Cășeiu subsector) with the Brezei Hill, a massive hill, mostly made of conglomerates and sandstones and the Ciceului Hills. The Muscelu hilly Massif, which ensures the passing from the Purcăreț Plateau towards the Ciceului Hills, is an important local orographic node, very significant for those times, considering the whole defence system in the region (Ferenczi, 1991, p. 132).

The Someșului Corridor favoured the connectionsbetween the watch stations and the signalling stations placed on the peaks of the surrounding hills, being significantly considered the connection between the two entrenchments in the $1^{\text {st }}$ and $2^{\text {nd }}$ century (Samum and Tihău) (Ferenczi, 1991, p. 134).

Cășeiu castrum was built in 106 A.D., simultaneously with the limes. It is located on the right bank of the Someş, on the meadow terrace, east of the confluence with Sălătrucul, $1.5 \mathrm{~km}$ from the current village, in the place called Cetăţele. The purpose of locating the camp at this point was to ensure the visibility and surveillance of the Someş corridor and to shelter the troops necessary to block the attacks from the north (Culmea Brezei, Lăpuș Depression), possible in the Poiana Valley and in the Sălătrucului Valley.

\section{The Roman limes - part of the regional identity?}

In this section, we made a brief analysis of the identity elements, in an attempt to find out how many of them refer to the Latin past and especially to the Roman limes.

In Tihău-Cășeiu area, the traces of the Roman limes are found mostly in the museums. The biggest part of the almost 2,000 years old borders' ruins has been destroyed in time, both by natural conditions and anthropic activities. The situation is quite similar all over the Romanian territory; that is why, in 2014, the Ministry of Culture established the Limes National Program (2015-2019). This program aimed to work on a specialized documentation regarding the remains and current monuments that constituted the Roman border of the Dacia province. The Romanian part of the limes is the largest unitary monument of heritage in Romania (Ministry of Culture, 2020). Being a heritage monument, the Roman limes is part of the elements of national identity: "The Roman cultural heritage has a privileged place in the Romanian identity and culture, as it is the evidence of the Latin inheritance" (Ministry of Culture, 2020). Therefore, the Romanian authorities and the public are interested in its protection and evaluation. It should also be mentioned their attempt to put the Frontiers of the Roman Empire - Dacia, on the UNESCO World Heritage List.

The representations of the limes are given by: 1) the archaeological evidence that has been discovered and which is still present in the field, 2) the archaeological discoveries which have been exhibited in the museums, and 3) images with the elements of the limes which can be found in historical publications. These images are reconstructive sketches of the limes made by specialists.

The History Museum of Dej, Cluj County, has numerous such pieces of evidence. The artifacts (represented mainly by vessels and tools), together with the inscriptions, are the main/physical representations of the Roman limes and of the system of fortifications. We considered relevant 
to illustrate some representative inscriptions, which attest the Roman presence in the territory; Figure 2 shows a series of stone tiles with the insignia of "cohors I Britannica milliaria civium Romanorum equitata" [cohorta I Britannica, civilian military army].

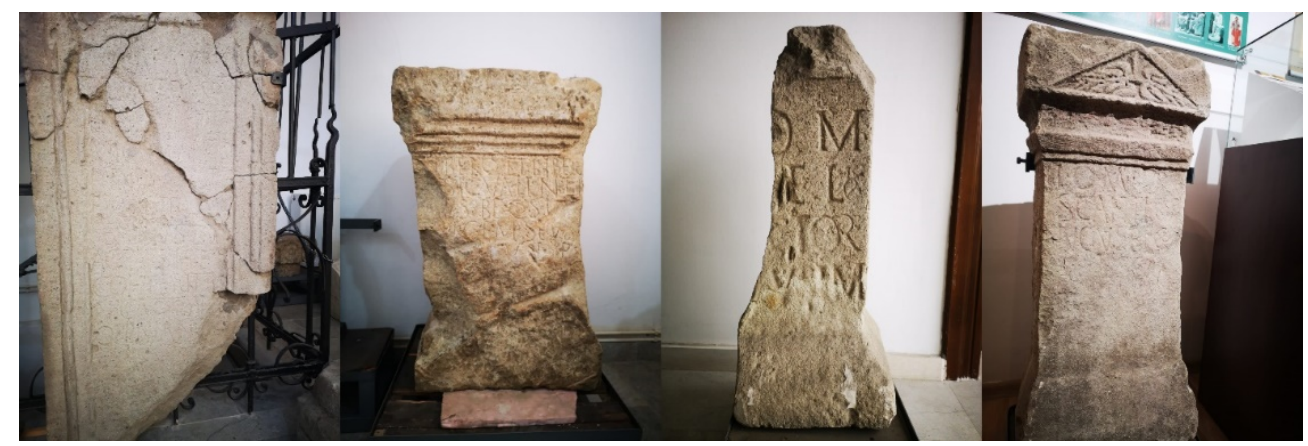

Figure 2: Inscriptions. The History Museum of Dej

Source: Personal archive of Ovidiu Rus, February 2020. Published with permission.

Also, there are a series of funeral emblems, represented by stone made sculptures. These are stone monuments, which were located above a tomb. They are traditionally used for funerals in Christian religions (see Figure 3 ).

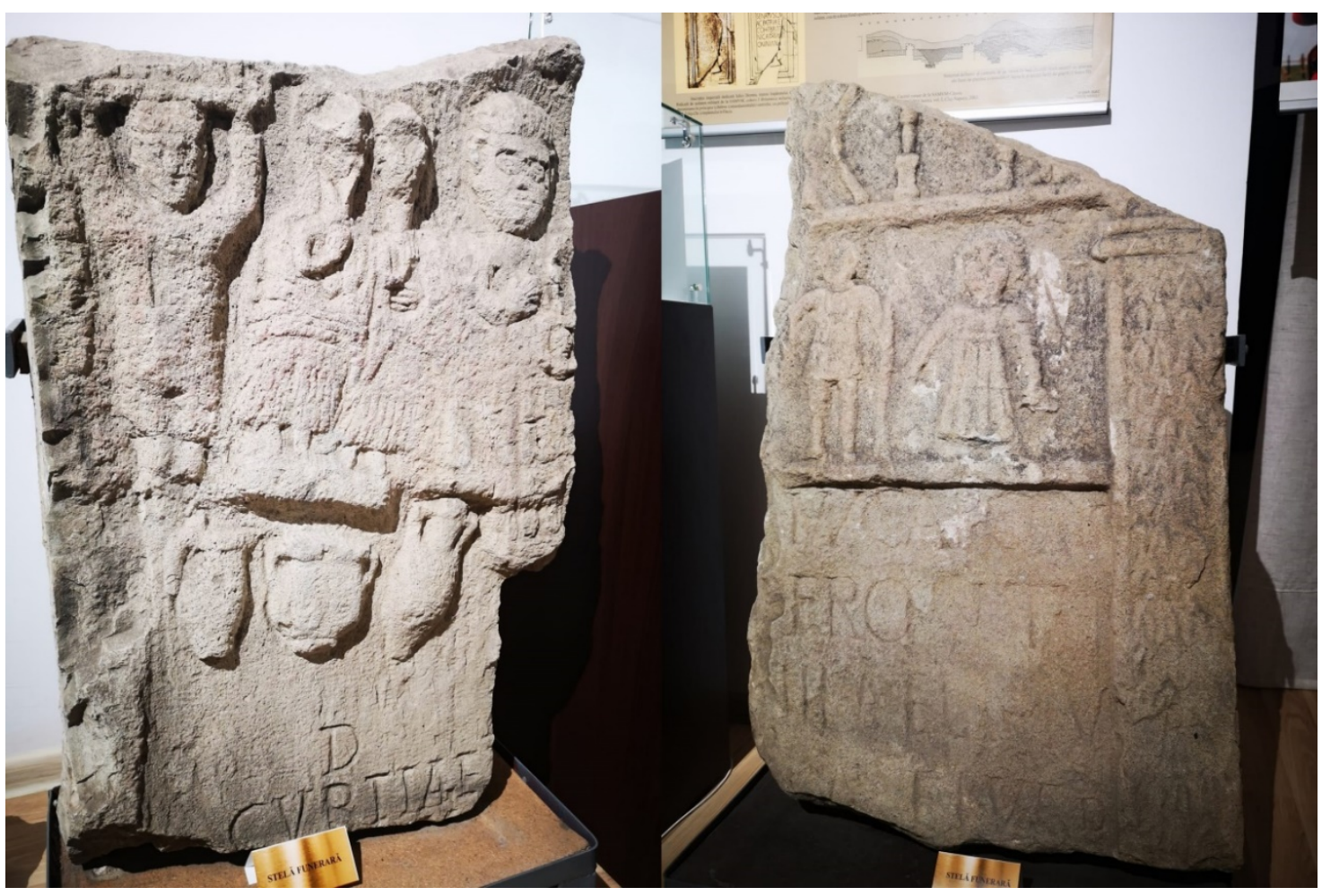

Figure 3: Funeral steles. The History Museum of Dej 
The track of the limes is hardly present in people's memory. From the discussions we had with the residents, we found out that the existence of limes or the fact that their area had an essential role in the defence of the Roman Empire has little emotional impact. The peoples and the empires which conquered this area promoted their specific elements (land use, daily activities, customs, and traditions). We noticed the lack of sense of belonging to the border area of the Roman Empire.

The Romanization of the Romanian people is a debated topic over time. The evaluation of the degree of Romanization of the Romanian people is not the object of study of the present article. Roman origins are part of our history, but in addition to Roman influences, there are many other influences. The Romanian Government presents Romania as "an island of Latinity in the Balkans" (Guvernul României, 2018).

In addition, we focused on the landforms, because of the important role they had for border tracing. Analysing the existing maps, we noticed that the altitude in the study area varies from $178 \mathrm{~m}$, the minimum height in the Someș meadow, to over $700 \mathrm{~m}$, as well as in the Toci Hill.

Considering the density of the landform fragmentation, the greatest part of the area has scores under $1 \mathrm{~km} / \mathrm{square} \mathrm{km}$, which is a proof that the hydrographic network is formed out of several temporary flows, the most relevant river being the Someș (see Figure 4). The relief energy map, resulted from the subtraction of the minimum altitude from the maximum altitude of a specific area, has predominantly the score of $100-150 \mathrm{~m} / \mathrm{km}$, which proves that there is a low dynamic and torrential activities.

Therefore, the stability of the terrain represents one of the main elements in the favourability of the region, a fact that enabled the border of the region to be drawn there ever since the Roman Empire. Good strategists, the Romans were choosing the safest areas for defence, and the TihăuCășeiu area was a point of interest for them based on the stability, the average heights, the petrographic composition and the specificity of the vegetation. The role that landforms had in drawing the border was critical, as showed previously through the analysis of the morphometric characteristics. This was supporting the defence of the northern border of the Empire.

For the regional identity, the structure of the relief had a double significance: one of favourability, enabling influences from outside the region, and one of restrictiveness, not allowing the region to be included in any kind of country formation. The outer influences can be spotted in the most prominent way in the traditional clothes where we can spot elements from the Land of Chioar, the Land of Lăpuș, and even from the Land of Năsăud and the Land of Silvana.

For the women's traditional clothes, we can spot the black aprons with fewer flowers on the bottom part, just like in the Land of Silvana. The shirt that they were wearing had long straight sleeves compared to the big, puffed sleeves worn in the other regions. On the other hand, for men's clothing, we find long and wide pants, like the ones in the Land of Lăpus. The girdle is brown and plain, being different from the other ones that we find in the adjacent lands where we can spot embroidered details.

These ethnographic elements cannot be related to the limes, they were mentioned only as identity elements. Earlier, the idea of evaluating them in order to see which and how many of them refer to the Roman Empire and limes was mentioned, and that is the reason why we talked about traditional clothes (perceived as an identity mark).

Although the Roman army withdrew from the present territory of Romania in the third century, the process of Romanization continued through the perpetuation of the Latin language, customs, and through the valorisation of the infrastructure built by the Romans (roads, settlements). All these elements contributed to the formation of the national identity. 

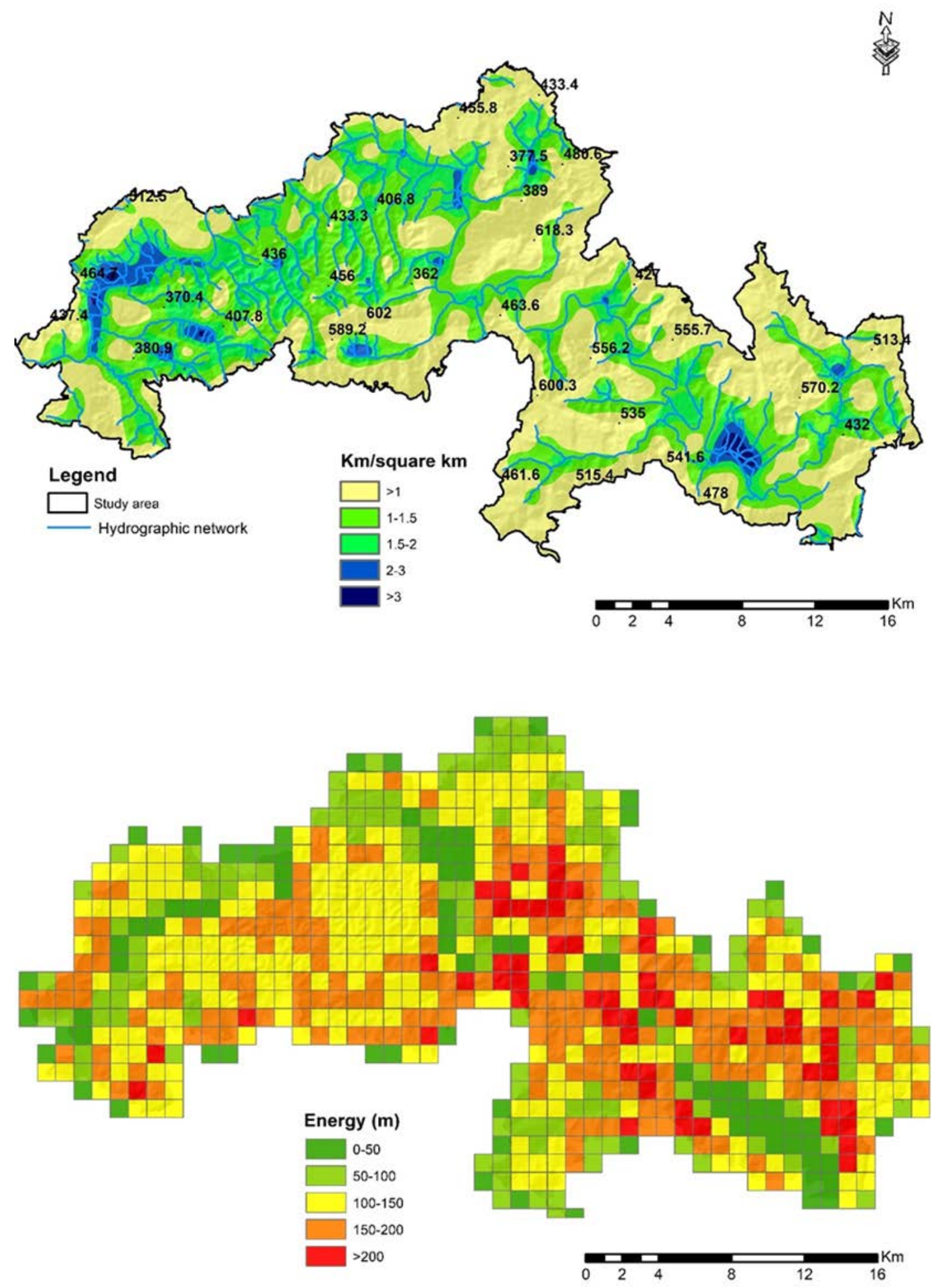

Figure 4: Drainage density and relief energy map

Author: A.-M. Colcer. Source of data:Shapefiles-GeoSpatial Website \& Copernicus Programme 
The migrant peoples (especially the Slavs) and the various rules under which the region was during centuries (e.g. Austro-Hungarian Empire) have a substantial impact on the spoken language, the landscape, the toponomy, on the customs, and on the daily activities.

The Roman foundation of our country has been strongly polished over time. This can be seen on a micro-scale - our study region. For example, the place-names in the region, according to Chende-Roman (2006) have predominantly Slavonic and Hungarian origins.

Slavonic are the following:

Lozna - the name comes from the Slavic word "vine" (Chende-Roman, 2006, p. 199)

Solna - meaning "salt" (Chende-Roman, 2006, p. 261)

Tihău - comes from the Slavic word "calm" (Chende-Roman, 2006, p. 280)

\section{Hungarian are the following:}

Ileanda-comes from the "Ilona" name (Chende-Roman, 2006, p. 185)

Cormeniș - comes from "köd" (meaning "fog") and "ménes" (meaning "stud") (Chende-Roman, 2006, p. 122)

Surduc-comes from "szurdok" meaning "gorge" (Chende-Roman, 2006, p. 267)

\section{Mixed origin has the following:}

Rogna - based on the Slavic word "ravinu," transformed by the Hungarians into "rovna," meaning "plateau" (Chende-Roman, 2006, p. 246).

To sum up, the Roman influence in toponyms is reduced. The references to the Roman period are vague, and non-existent to the limes.

\section{Online representations of the limes as part of the local identity}

We started by searching the following terms on Google: the name of the commune (e.g. Cășeiu commune, Vad commune and so on). For each, we analysed every results page (they were eight pages of results with ten links on each). We divided these sites into three categories: official sites (such as municipal administration websites, ministry websites, county council websites, etc.), useful information sites (such as Wikipedia, tourism promotion centres, sites that contain information regarding postcodes, etc.), and social media pages. Each commune has a website where we could browse for various pieces of information.

For Cășeiu commune, we found the highest number of images on the Facebook profile of the settlement centre. More than one hundred albums have pictures from different events: Rugășești Party, Carols concert, The Sickling Garland agricultural custom ("Cununa Secerișului”) (Centrul Turistic Cășeiu, 2020), the harvest day. These events have a local character with many participants so there are numerous posts and images on social media platforms and on other online public or private sources.

There is an album with ten pictures from the Roman castrum of Cășeiu. Those pictures came from archaeological excavations, others with the plan of the castrum and another one has an old popular song, where the toponym "cetățele" (the place where the castrum is situated) is 
found: "de-arfi jocu-n cetățele/Fetele pi-acolo-ar mere/Şi babele după ele" [if the dance would be in Cetățele/There is where the maidens would go/ and the hags would follow].

More than forty albums are on the page called "I love Vad" (I Love Vad, 2020). The most exhibited local landscapes are from the surroundings. The album called "Cetatea Ciceului" [Ciceului fortress] (I Love Vad, 2013) exhibiting local pictures demonstrated the sense of belonging of the people in the Land of Ciceu. Ten albums contain older and newer pictures realised by the inhabitants. Other albums contain images of different churches from the component localities, which demonstrates the inhabitants' religiosity. What caught our attention was the album called "șurile ochioase" [barns with eyes] (I Love Vad, 2017), having five pictures with tall barns, two rows of small windows, a V-shaped roof, but with a flattened tip. The attic was used for storing animal food. "În casa bunicilor" [In grandparents' house] (I Love Vad, 2019a) has seven pictures of traditional interior design: towels above doors and religious paintings with saints, small clay plates hanged on the walls, "păretare" (pieces of embroidered canvas on the walls) and "lepedeu" (colourful bed sheets).

For the communes of Sălaj County, we found an advertising page, called "Hoinar prin Sălaj" [Wandering through Sălaj] (Matyas et al., 2020). Among the many albums on this page, we found around twenty albums with landscapes from the villages, with pictures of old houses and churches.

Thus, by analysing the images published on Facebook, it could be observed that the main role of the pages is information and promotion. The images and information coming from these pages capture natural landscapes from the settlements, followed by the images with a religious character, representing churches and religious practices and holidays. From the descriptions of the pictures and the comments left by visitors, there was a nostalgic scent and also the pride of belonging to those places. Descriptions such as: "Vadu nost" [our Vad] (I love Vad, 2019b), "Grădinile din Vad sunt pline de surprize. Și culoare" [The gardens in Vad are full of surprises and colours] (I love Vad, 2014) and comments like: "Ceva ce nu se poate uita" [Unforgettable] (E.B., 2019), "Ce amintiri frumoase" [Wonderfulmemories] (C.L., 2019), can easily be found on each page.

None of the Facebook profiles and pages mentioned above have a verified badge on Facebook. We considered it essential to see how locals promote their communes and especially what they consider relevant and specific for their places. We only mentioned here the most significant Facebook pages, every commune has a Facebook page or profile, but the information found there was poor.

On YouTube, we found a tourist promotion video of Cășeiu. That video was posted by a private person, Dorin Prunduș, in 2015. The "ethnographic mixture" (Prunduş, 2015), which is specific to that area, is given by the proximity of the Land of Lăpuș, Land of Năsăud, and the Someș Valley. In the past, the houses were similar to those from the Land of Lăpuș and the Someș Valley - small and straw-covered houses. The Roman castrum from Cășeiu has less than one minute of the 22 minutes video.

For Coplean, the video presents the Haller Castle - the castle with shells, built in the $18^{\text {th }}$ century (Clujul2009, 2010).

Vad commune does not have a tourist promotion video. We chose other videos, especially interviews with the inhabitants. In most videos, specific, old, blue-painted houses are present. We also found videos of an old man recollecting his memories from the Second World War, and 
a local wedding tradition called "cu găina la nănaș" [with the hen at the godfather's] (Dej24 Știri din Dej, 2019), which involves a series of specific woes.

For lleanda, a video presenting a 200-year-old house sparked our interest. It is a small, old, and blue house with a thatched roof. It is still inhabited and visited by tourists (ZTV, 2014). For Gâlgău, going around the house three times with incensing and cleaning of the yard and trees are considered good luck bringing habits (Regio TV Transilvania, 2016).

Another significant video we found was the documentary of the Rus commune, which is not available on YouTube. We will mention it as well because this subchapter examines the videos. The three-hours documentary has vast information about the commune, its history, customs, habits, and traditions. All these traditions are numerous, but we only chose the ones which are local, because the biggest part of it is specific for the whole north Transylvania. These two unique habits are "ciocota" [egg clash] and "moșuții" [ancestors] (Redacția Transilvania TV, 2018). The first of them involves the clash of a large number of boiled and painted eggs on Easter Sunday, after the service, by the men, in front of the church. The origin of this custom is unknown, but it is firmly rooted in local practices.

The second custom involves dressing two young boys in a garment made of straw (or hay) and wearing coloured masks on their faces. On New Year's Eve, the two men go from house to house, where they dance. It is an agrarian, pre-Christian custom. Straw falling on houses brings abundance and health.

After analysing the video sources, we can conclude that the study area is rich in identity elements. We notice the numerous wooden churches, two-three centuries old, the old houses, painted in blue, with the shingles roof. The ethnographic mixture, due to the location of the study area, is what gives uniqueness.

From the official websites, we chose the site of the town halls. For the communes of Cășeiu, Vad, Lozna, Băbeni, Gâlgău, Surduc, only administrative information can be found, such as management, organization charts, decisions of the local council, projects, announcements and information of public interest, such as budget, balance sheets and useful documents. Most of the websites were not functioning.

Information about the history and traditions of the commune can be found on the website of the mayor's office in Câtcău. As a specific element, "fiii satului" [sons of the village] (Comuna Câțcău, 2020), is an event that takes place every June. Its purpose is to preserve the local tradition and to bring together the people, from the youngest to the oldest, who were born there but live in other places.

There is a section with the following elements: traditions, churches, places to visit on the website of the town hall of lleanda and Rus communes. They reflect the elements that the public authorities consider representative of their commune, which are identic with the images found on Facebook or YouTube.

While searching on Google, we found that Vad commune is part of the project called "Remarkable Romania" (Centrul Cultural Clujean, 2020) a national program, label type, which creates a network of localities that adopt strategies and programs for local development through heritage and culture. Among the events organized by this project is "Sânzâiene," a tenday event, where a series of traditional activities and cultural events for visitors will be held.

Last but not least, there are three Centres for Information and Tourism Promotion in the study area, two of them having a website. The Centre in Cășeiu has the same information found on the earlier mentioned touristic video. 
We will focus on the Tourism Promotion Centre of Gâlgău. Numerous representations of their identity can be found there: the Roman vestiges from Căpâlna fortress, the Virgin Mary wooden church in Bîrsău Mare dating back to 1690, the Saint Nicolaus wooden church in Fodora built-in 1817, the School Museum in Gâlgău, Mihaly House in Chizeni, and the cave in Frîncenii de Piatră. The church in Bîrsău Mare has, on the beam between the nave and altar, an inscription showing that the church was painted in the days of Joseph II. The church of Fodora has biblical texts written in Romanian, Latin, Hungarian and German on its wooden walls (Centrul Turistic Gâlgău, 2020).

As can be seen, very few elements could be associated with the Roman past - few information about the Cășeiu castrum, the pre-Christian custom in Rus commune.

The churches have been built starting with the $17^{\text {th }}$ century and prove the religious character of the inhabitants. The Haller Castle, a significant monument of art and architecture in Transylvania, refers to the Austro-Hungarian Empire, given that it belonged to the Haller family (Ordinul Arhitecților din România, 2015). The construction material used to build the castle is the stone brought from the castrum in Căşeiu. The period of Austro-Hungarian rule is also represented by the inscription in the church of Fodora. The events of the last century, more precisely of the world wars, are held in the memory of the inhabitants. These events are present in their memory by the fact that they lost their relatives. The story of Mr. Petrea Toderean being one of the few oral testimonies of the live war experience (the event he talks about took place in 1942) (Ciunterei, 2019).

\section{CONCLUSIONS}

The borders of Dacia Porolissensis are a clear example of exploiting the geographic and the geomorphological factors in favour of the tactical element. The geographical characteristics of the Tihău-Cășeiu sector have imprinted on the Romanian border its own appearance, the spatial distribution of the structural elements falling within a Terrain Following System. This type of borderfollows the maximum use of the topographic level for allowing a good visibility system.

The study area was never a compact and homogenous region. It has been divided several times, during history, into various territorial structures. Tihău-Cășeiu area has some border-region characteristics. Being part of various lands, counties and regions, the region has undergone external changes and influences. It is precisely this aspect that gives this study area an element of specificity.

The identity elements are shaped by a mix of external influences, materialized in the traditional costume, folklore, and architecture. But these are unevenly divided on the study surface. The representations of the limes and the Roman fortifications system are found in the historical publications, but they are missing in the popular culture (poems, songs). The most notable are the Slavic and Hungarian influences. The latter is due to the long Hungarian rule in the territory.

The reason why we chose this area of study was its importance for drawing the Roman border; however, in terms of identity elements, the Roman limes and its remains are not relevant for the population.

From the analysis of the online information, we could notice a few references made to the Roman past. Most information about the Roman limes is found in Cășeiu commune, due to its castrum. Instead, the discourse on local identity and the representations of these elements of identity are given by relatively recent events. 


\section{REFERENCES}

BUTLER, A., KNEZ, I., AKERSKOG, A., SARLOV HERLIN, I., ODE SANG, A., \& ANGMAN, E. (2019). Foraging for Identity: The Relationships between Landscape Activities and Landscape Identity after Catastrophic Landscape Change. Landscape Research, 44(3), 303-319, DOI:10.1080/01426397.2019.1580352

C.L. (2019). Ce amintiri frumoase [Wonderful Memories]. In I Love Vad Facebook Page. Retrieved 24 April 2020, from https://www.facebook.com/hoinarprinsalaj/photos/a.815098818832720/815099348832667/?type=3\&theater

CAPELLO, R. (2018). Interpreting and Understanding Territorial Identity. Regional Science Policy \& Practice, 11(1), 141-158.

CENTRUL CULTURAL CLUJEAN [CLUJ CULTURAL CENTER] (2020). România Remarcabilă [Remarkable Romania]. Retrieved 15 April 2020, from https://romaniaremarcabila.ro/

CENTRUL TURISTIC CĂȘEIU [CENTRE FOR INFORMATION AND TOURISM PROMOTION CĂȘEIU]. Facebook Page. Retrieved 24 April 2020, from https://www.facebook.com/centrulturistic.caseiu.5

CENTRUL TURISTIC GÂLGĂU (2020). Obiective turistice [Touristic Attractions]. www.gilgau-turistic.ro

CHENDE-ROMAN, G. (2006). Dicționar etimologic al localităților din Județul Sălaj [Etymological Dictionary of Settlements from Sălaj County]. Zalău: Caietele Silvane.

CIUNTEREI, I. (2019). O adevărată lecție de istorie - badea Petrea Toderean - Bogata de Jos, com. Vad, jud. Cluj [A Real History Lesson with Petrea Toderean - Bogata de Jos, Vad Commune, Cluj County]. Posted on 18 October 2019. Retrieved 27 April 2020, from https://www.youtube.com/watch?v=v1xfurWhaFU

CLUJUL2009 (2010). Castelul Haller din Coplean, Cluj [Haller Castle in Coplean, Cluj County]. Retrieved 24 October 2020, from YouTube, https://www.youtube.com/watch?v=OXtZ3q0kECY\&t=8s\&ab_channel=clujul2009

COLCER, A.-M. (2017). Diary. In Ilovan, O.-R. \& Doroftei, I. (eds.), Qualitative Research in Regional Geography. A Methodological Approach (pp. 131-146). Cluj-Napoca: Presa Universitară Clujeană.

COMȘA, E. (1987). Neoliticul pe teritoriul României: Consideraţii [Neolithic in the Romanian Territory: Considerations]. București: Academia Socialistă România.

COMUNA CÂṬCĂU [CÂTCĂU COMMUNE] (2020). Istoric, tradiții și așezare [History, Traditions and Geographical Location]. Retrieved 24 April 2020, from https://www.primariacatcau.ro/ro/pagina?slug=istoric-traditii-siasezare-geografica

COPERNICUS PROGRAMME (2020). EU-DEM v1.0. Retrieved 3 April 2020, from https://land.copernicus.eu/imageryin-situ/eu-dem/eu-dem-v1-0-and-derived-products

DEJ24 ȘTIRI DE DEJ [DEJ24 DEJ NEWS] (2019). Cu găina la nănaş. Bogata de Jos, comuna Vad, Cluj, Rusalii [With the Hen at the Godfather's. Bogata de Jos, Vad commune, Cluj, Pentecost]. Posted on 17 June 2019. Retrieved 28 April 2020, from https://www.youtube.com/watch?v=sDRz4Dj_vm0

DIXON, J. \& DURRHEIM, K. (2000). Displacing Place-Identity: A Discursive Approach to Locating Self and Other. British Journal of Social Psychology, 39, 27-44.

E.B. (2019). Ceva ce nu se poate uita [Unforgettable]. In I Love Vad. Retrieved 24 April 2020, from https://www.facebook.com/ILoveVad/photos/a.702856759760280/2219624471416827/?type=3\&theater

FERENCZI, I. (1988). Limes-ul Dacic. Sectorul de pe Someșul Unit. Elementele de apărare pe subsectorul Ileanda-Tihău. [Dacian Limes. Someș Sector. Elements of Defence on the Ileanda-Tihău Subsector]. Acta Mvsei Porolissensis, $12,251-289$.

FERENCZI, I. (1991). Limes-ul Dacic. Sectorul de pe Someșul Unit. Elementele de apărare pe subsectorul CășeiuIleanda. [Dacian Limes. Someș Sector. Elements of Defence on the Cășei-Ileanda Subsector]. Acta Mvsei Porolissensis, 14-15, 127-161.

FERENCZI, I. (1992). Contribuţii la problema cunoaşterii sistemului de apărare roman de pe cursul Someşului. [Contributions to the Knowledge of the Roman Defence System on the Someș Valley]. Acta Mvsei Porolissensis, 24-25, 171-191

GECAS, V. \& BURKE, P. (1995). Self and Identity. In Cook, K., Fine, A. \& House, J. (eds.), Sociological Perspectives on Social Psychology (pp. 41-67). Boston: Allyn and Bacon. 
GEOSPATIAL ORGANIZATION (2019). Spatial Data. Retrieved 23 July 2019, from http://geo-spatial.org/

GUVERNUL ROMÂNIEI [ROMANIAN GOVERNMENT] (2018). Film de prezentare a României la sărbătorirea Centenarului [Romania's Film Presentation at the Centenary Celebration]. Retrieved 24 April 2020, from https://www.youtube.com/watch?v=Bta08vV_mSM\&feature=emb_logo

I LOVE VAD (2013). Cetatea Ciceului [Ciceului Fortress], Facebook album. Retrieved 23 April 2020, from https://www.facebook.com/media/set/?vanity=ILoveVad\&set=a.521614111217880

I LOVE VAD (2014). Grădinile din Vad sunt pline de surprize. Și de culoare [The Gardens in Vad are Full of Surprises and Colours], Facebook photo description. Retrieved 23 April 2020, https://www.facebook.com/ILoveVad/photos/a.702856759760280/712695945443028/?type=3\&theater

I LOVE VAD (2017). Șurile ochioase [Barns with Eyes], Facebook album. Retrieved 23 April 2020, from https://www.facebook.com/media/set/?vanity=ILoveVad\&set=a.1439417996104149

I LOVE VAD (2019a). În casa bunicilor [In Grandparents' House], Facebook album. Retrieved 23 April 2020, from https://www.facebook.com/media/set/?vanity=ILoveVad\&set=a.2306902602689013

I LOVE VAD (2019b). Vadu' nost [Our Vad], Facebook photo description. Retrieved 23 April 2020, https://www.facebook.com/ILoveVad/photos/a.702856759760280/2433745093338096/?type=3\&theater

I LOVE VAD (2020). Facebook Page. Retrieved 23 April 2020, from https://www.facebook.com/ILoveVad/

ILOVAN, O.-R. (2008). Raportarea la trecut sau semnificaţia unei perioade istorice pentru identitatea teritorială năsăudeană [Considering the Past or the Significance of a Historical Period for the Territorial Identity of Năsăud Region]. In Bolovan, I., Mureşan, C., \& Hărăguş, M. (eds.), Perspective demografice, istorice şi sociologice. Studii de populaţie [Demographic, Historical and Sociological Perspectives. Population Studies] (pp. 363-406). Cluj-Napoca: Presa Universitară Clujeană.

ILOVAN, O.-R. (2009). Tara Năsăudului. Studiu de Geografie Regională [The Land of Năsăud. Study of Regional Geography]. Cluj-Napoca: Presa Universitară Clujeană.

ILOVAN, O.-R. (2015). Metodologia identificării trăsăturilor identitare locale. Studiu de caz: identitatea comunităţii din Runcu Salvei, Jud. Bistriţa-Năsăud [The Methodology for Identifying Local Identity Features. Case Study: The Identity of Runcu Salvei Community]. Geographia Napocensis, 9(2), 29-38.

ILOVAN, O.-R., MAROȘI, Z., ADOREAN, E.-C., URSU, C.-D., KOBULNICZKY, B., DULAMĂ, M.E., \& COLCER, AI.-M. (2019). Learning and Research by Integrating the ICT and the Theory of Representations: Mapping the Industrial Areas of Cluj-Napoca. Romanian Review of Geographical Education, 8(2), 58-77. DOI: 10.24193/RRGE220194

ILOVAN, O.-R., PETER, J., HAVADI-NAGY, K.X., \& ZAMETTER, T. (2016b). Identity Matters for Development: Austrian and Romanian Experiences. Transylvanian Review, 25(1), 261-276.

ILOVAN, O.-R., SCRIDON, I., HAVADI-NAGY, K.X., \& HUCIU, D. (2016a). Tracing the Military Frontier District of Năsăud. Territorial Identity and Regional Development. Mitteilungen der Österreichischen Geographischen Gesellschaft, 158, 215-244.

ILOVAN, O.-R., VOICU, C.-G., \& COLCER, A.-M. (2019). Recovering the Past for Resilient Communities: Territorial Identity, Cultural Landscape and Symbolic Places in Năsăud Town, Romania. Europa Regional, 26.2018(2), 1428. https://nbnresolving.org/urn:nbn:de:0168-ssoar-66830-6

JOHNSON, C., JONES, R., PAASI, A., AMOORE, L., MOUNTZ, A., SALTER, M., \& RUMFORD, C. (2011). Interventions on Rethinking 'the Border' in Border Studies. Political Geography, 30, 61-69.

MARCU, F. (2017). Terminologia latină privind granița romană [The Latin Terminology Regarding the Roman Border]. Buletinul Limes, 2, 4-10. Retrieved 10 April 2020, from https://limesromania.ro/ro/download/?id=492\&tk=91df2a6f9b68b631fe328fdf8e8c4fb7681bd92d

MARCU, F., CUPCEA, G., BAJUSZ, M., PETIȘ, I., COCIȘ, H., \& ZĂGREANU, R.I. (2017). Frontiera Daciei Porolissensis între Castrele de la Tihăuși Cășeiu (Samum) [Dacia Porolissensis' Border between Tihău-Cășeiu Castrums]. Buletinul Limes, 2, 20-25.

MAROȘI, Z., ADOREAN, E.-C., ILOVAN, O.-R., GLIGOR, V., VOICU, C.-G., NICULA, Al.-S., \& DULAMĂ, M.E. (2019). Living the Urban Cultural Landscapes in the City Centre of Cluj-Napoca/ Kolozsvár/ Klausenburg, Romania. Mitteilungen der Österreichischen Geographischen Gesellschaft, 161, 117-160. 
MATYAS, M., FODOCA, C., CRISTE, M., \& M.T. (2019). Hoinar prin Sălaj [Wandering through Sălaj]. Facebook Page. https://www.facebook.com/hoinarprinsalaj

MINISTRY OF CULTURE (2020). World Heritage List. Frontiers of the Roman Empire - Dacia. Submitted on 31.01. 2020. Retrieved 14 April 2020, from https://whc.unesco.org/en/tentativelists/6447/

MUZEUL JUDEȚEAN MUREȘ [MUREȘ COUNTY MUSEUM] (2020). Roman Limes Route. Retrieved 20 January 2020, from http://www.limesdacicus.ro/limes/

ORDINUL ARHITECTIILOR DIN ROMÂNIA [ROMANIAN ORDER OF ARCHITECTS] (2015). Monumente uitate. Coplean Haller [Forgotten monuments. Coplean - Haller]. Retrieved 13 April 2020, from http://monumenteuitate.org/ro/monument/287/Coplean-Haller

PAASI, A. (2000). Territorial Identities and Social Constructs. International Social Science Review, 1, 2-22.

PAASI, A. (2002). Bounded Spaces in the Mobile World: Deconstructing 'Regional Identity'. TESG: Journal of Economic and Social Geography, 93(2), 137-148.

PAASI, A. (2003). Region and Place: Regional Identity in Question. Progress in Human Geography, 7(1), 475-485.

POTRA, A.-C. (2017). Tinutul Ciceului. Analiză regională [County of Ciceu. Regional Analysis]. Cluj-Napoca: Risoprint.

PRUNDUȘ, D. (2015). Video. Prezentare turistică Comuna Cășeiu [Video. Tourist Promotion of Cășeiu Commune]. Posted on 9 April 2015. Retrieved 28 April 2020,

from https://www.youtube.com/watch?v=Y1ah5jBc9vc\&ab_channel=DorinPrundus

REDACȚIA TRANSILVANIA TV [TRANSILVANIA TV EDITORIAL OFFICE] (2018). Centenar: Localitatea Rus va rămâne în istorie, cu un documentar de lung metraj [Centenary: Rus Village Will Go Down in History with a FeatureLength Documentary]. Sălaj News. Retrieved 26 April 2020, from https://salaj.transilvania-tv.ro/centenarlocalitatea-rus-va-ramane-istorie-cu-un-documentar-de-lung-metraj-video/

REGIO TV TRANSILVANIA (2016). Tradiţii populare la Gâlgău [Popular Traditions at Gâlgău]. Posted on 23 March 2016. Retrieved 28 April 2020, from https://www.youtube.com/watch?v=RK6T27SFacl

RUS, O. (2020). Pictures of the History Museum of Dej. Personal collection.

SĂGEATA, R. (2013). Organizarea administrativ-teritorială a României. Evoluție. Propuneri de optimizare [The Administrative-Territorial Organization of Romania. Evolution. Optimization Proposals]. București: Academia Română, Institutul de Geografie.

SCRIDON, I. \& COLCER, A.M. (2017). Cross-cultural Research. In Ilovan, O.-R. \& Doroftei, I. (eds.), Qualitative Research in Regional Geography. A Methodological Approach (pp. 187-204). Cluj-Napoca: Presa Universitară Clujeană.

SCRIDON, I. \& ILOVAN, O.-R. (2015). The Zipsers' Ethnic Identity in Vişeu de Sus/Oberwischau, Romania, in the Context of Inter-Ethnic Relationships. Mitteilungen der Österreichischen Geographischen Gesellschaft, 157, 151-168.

SCRIDON, I. \& ILOVAN, O.-R. (2016). Approaching the Other in the Zipsers' Community. Identity Issues and Methodological Insights into Geographical Cross-Cultural Research. Transylvanian Review, 25(1), 55-73.

TWIGGER-ROSS, C. \& UZZELL, D. (1996). Place and Identity Processes. Journal of Environmental Psychology, 16, 205-220.

ZTV (2014). Casa de povești din localitatea Răstoci [Fairy House from Răstoci], by Anca Schlachter and Arnold Schlachter. Posted on 8 August 2014. Retrieved 28 April 2020,

from https://www.youtube.com/watch?v=PQlpcH4Odek 